\title{
Troubling Talk: A Politics and History of Indistinction in the Upper Sorbian Community
}

\author{
ElizABeth SPREnG \\ Miami University, 130 Upham Hall, Oxford, OH 45056, ZDA \\ sprengea@miamioh.edu,worldethno260@gmail.com
}

\begin{abstract}
SCN VI/1 [2013], 5-17
The article focused on the cultural processes that affect speakers of Upper Sorbian, an endangered Slavic community in Eastern Germany. Through an anthropological approach, language choices emerge as a complex negotiation of linguistic identity evidenced in critique of other Sorbs and language use as well as choosing to distance oneself from the community.

Prispevek se osredinja na kulturne procese, ki vplivajo na govorce gornje lužiščine, ogrožene slovanske skupnosti v Vzhodni Nemčiji. Antropološki pristop razkriva, da se jezikovna izbira pojavlja kot kompleksno pogajanje z jezikovno identiteto, kar se potrjuje v kritiki drugih Srbov in rabe jezika ter v distanciranju posameznika od skupnosti.
\end{abstract}

Key words: language endangerment, globalization, ethnography

Ključne besede: jezikovna ogroženost, globalizacija, etnografija

The Sorbs have been crying wolf for a thousand years, but their language is still not dead,

- Tom, a Sorbian theater worker

In many endangered settings, bilingual speakers talk about the linguistic troubles facing them. ${ }^{1}$ During my research in Lusatia, Saxony (Summer 2004, 2005 and Sept. 2006-Dec. 2007), I investigated the complicated emotional dynamics

\footnotetext{
${ }^{1}$ From this point, I will use "Sorb" to refer to Upper Sorbian speakers. This nomenclature of using the word "Sorb" to refer to both the language and the speakers is one that Sorbian academics view as correct English usage. In addition, I italicize Sorbian text and underline and italicize German text. My last stylistic point is the use of SMALL CAPS for paper-specific terms that I am introducing in my arguments.
} 
of language shift in the Upper Sorbian community. ${ }^{2}$ Facing a future in which this Slavonic language may no longer be spoken, bilingual Sorbs often complain about the place of language in their everyday lives. In this paper, I offer a theoretical term - INDISTINCTION - to think about how endangered language speakers "fight" for linguistic survival by complaining, not speaking the language, not wanting to socialize, or becoming indistinct in their community. Interwoven with Sorbian vitality are historical issues about national status, economic issues, language ideologies, and linguistic survival.

From a scholarly perspective on emotions (Ahmed 2010; Berlant 2011) complemented by discussions in linguistic anthropology (Abu-Lughod 1986; Besnier 2009; Reis 1997; Wilce 1998, 2009), this paper explores the activities of talking about the troubles of endangerment and well-being. The various forms of TROUBLING TALK reveal a politicization of linguistic practices to such an extent that many often do not want to speak Sorb at all or to be around other Sorbs. Aligned with other anthropologists interested in language shift and code-switching (Cavanaugh 2009; Hill and Hill 1986; Hoffman 2008; Woolard 1989), I argue that intra-societal factors play a critical role in language loss that cannot be averted by language preservation measures; for example, institutional support and legal policy. Moreover, these activities of linguistic and social distancing constitute a range of strategic choices that fuel inter-Sorbian acrimony. By tacking back and forth between contemporary dynamics and historical conjunctures, I attend to INDISTINCTION as a politicized discourse and its inherent contradictions that connects ordinary suffering with broader concerns about nationalism, language policy, and multiculturalism.

Following the paradigm of language as social action, I introduce the concept of INDISTINCTION to consider the relationship between culture, language use, and selfhood. When I asked Sorbs about language use, they often responded by describing local politics that indexed urban-village stereotypes. Urban elites affiliated with Sorbian-only spaces in the town of Bautzen critiqued villagers for mixing tongues. Villagers denounced the "fat cats" who work for the urban institutions for linguistic snobbery. These local dialogues about language use entail a complicated navigation of devaluing and valorizing language mixing and standardized usage while exposing widespread unhappiness.

INDISTINCTION, to provide a starting point, is a not-wanting to be identified with a particular group that emphasizes affect and sociality in the judgment of tastes. This desire to not be identified with a particular identity can stem from a variety of motivations: negative stereotypes, long-term structural inequalities, or pressures to be a good example of said group to which a person self-identifies. Although from a first glance, indistinction is not an inversion of Bourdieu's (1994) classic discussion of class-based tastes. Instead, I argue that all aesthetic possibilities may be undesirable. To apply this to contexts of language shift, I posit that one language variety may not be unilaterally pref-

${ }^{2}$ This area Lusatia (Lautsitz, Eužica) was settled in the sixth century by original Slavic tribes. Only the Łužici (8,000 Upper Sorbs) and Milčeni (2,000 Lower Sorbs) survived. 
erable and all options may be subject to critique. These critiques are what I identify as TROUBLING TALK, a set of local discourses that significantly affected data collection, both positively and negatively.

While many Sorbs avoid discussions of endangerment, they often engage in urban-village gossip, a form of TROUBLING TALK. This gossip often concerns shared ideas about who speaks well and who doesn't. In these discussion, urban/village Sorbs strategically sidestep explicit assessment of their plight while critiquing language use. Thus, the politics of InDISTINCTION drives TROUBLING TALK. Yet, at the core of INDISTINCTION lies a paradox - while Sorbs participate in a politics of INDISTINCTION they also feel impassioned to such an extent that they distance themselves from the Sorbian interactions, express frustrations about social relations, or refuse to talk to an anthropologist. From this anthropological perspective, I hope to show that as Sorbs manage their everyday attachments to a disappearing language, their acts of resistance become practices of surviving.

To illustrate the ethnographic profundity of "being indistinct," the difficulties in scheduling a meeting with Laura, a fifty-something art teacher, capture the unexpected issues related to data collection. When we first met at the Sorbian Tourist Center, Laura and I talked as she gave a demonstration of painting Sorbian Easter eggs. As we chatted, I had little idea that she was deeply troubled about being a Sorb. Several weeks later, we met again at the middle school. Laura introduced me to her colleagues in the teacher's lounge with obvious pride describing my interest in the Sorbian community. This pride seemed at odds with being "alone in the basement," a comment that she made not five minutes later. In this back-handed snippet of TROUBLING TALK, I sensed Laura's anger at the physical and professional demotion associated with a forced change in career. During socialism (1947-1989) in the German Democratic Republic, she was a teacher in a Sorbian-only school. Yet now, Laura teaches her native tongue as a foreign language to students who have not done their homework. Similar to the way she introduced me to her colleagues, Laura, in her classroom, waxed poetically about the importance of my research but privately felt great conflict about local politics, endangerment, and language use.

This vivacious woman repeatedly refused to meet with me outside of the school to reflect on the Sorbian language. Her avoidance of an interview outside of school constituted self-silencing. After numerous phone calls, she finally admitted that she only wanted to work in her garden. She further explained that she did not want to see another Sorb, speak Sorb or talk about Sorbian issues. When she said, "I only want to have peace," I experienced an ethnographic epiphany: Laura recognized her own losing battle to be a "good" Sorb. Ironically, she still had to work in an uncomfortable space where she had to speak the language with others who cared little for it. By choosing not to speak Sorb outside of work, Laura was making a stand while finding a way to survive linguistically and emotionally. At the same time, her desires to have peace exemplify a longing for INDISTINCTION. Her need to separate from local politics and associated personal interactions intimates the political realities of 
ordinary suffering when every day is a struggle for survival in the basement or in the garden.

Distancing and emotional discontent index the urban-village discourses of difference via "drastic disturbances" (Bateson 1935) to the fabric of social relations. Sorbs often allude to their turmoil in TROUBLING TALK, practices of not speaking Sorb, and other ways to be indistinct. However, not actively using Sorb every day, talking about other Sorbs, or moving away from Sorbian contexts does not mean that individuals have accepted their fate or that they are powerless. Rather than considering Sorbs helpless in the march of time, I argue that a politics of INDISTINCTION and TROUBLING TALK provides a defense, albeit problematic, against continuing threats to their survival.

In thinking about survival despite overwhelming odds in American spaces, Berlant considers cruel optimism a condition of ordinary life in which "people learn to identify, manage, and maintain the hazy luminosity of their attachment to being $\mathrm{x}$, given that their attachments were promises and not possessions after all (Berlant 2011: 44)." The cruel optimism regarding contemporary moments is an on-going consideration of the uncertain future riddled with anger, acceptance of loss, and deep emotional wounds related to language and selfhood.

Although Sorbs use multiple Sorbian varieties as they speak, read, write, and hear more than one language, it is theoretically difficult to simply discuss binaries such as monolingual/bilingual and German/Sorbian. Sorbs consider themselves bilingual speakers and express an awareness of their hybridity (Tschernokoshewa and Jurić-Pahor 2005) supported in their descriptions of "having two roots" and speaking "mish-mash." By contrast, many Sorbs describe themselves as pure Sorbs. These multiple categories speak to a keenly described paradox - "die Realität ist jedoch nicht schwarzweiß" ("the reality is not simply black and white') (Šatava 2005: 25). This lived reality of not having a clear-cut identity reinforces a politics of INDISTINCTION and engagement in TROUBLING TALK.

Bilingual Sorbs reject identifications of an "either-or" paradigm and espouse a "not only-but also" logic that expresses a paradox related to selfhood. Šatava describes the latter as a third path that resonates with INDISTINCTION as praxis. This logic challenges assumptions that Sorbs are either Sorb or German - and - either monolingual or bilingual. Linguistically, Sorbs describe this enigma as speaking "/mish-mash/," a range of practices using standardized/ non-standardized resources. However, ideas about mish-mash are not without ideological contradictions, because mish-mash is not about Sorbian/German distinctions. Sorbs navigate this conundrum through a range of practices from not speaking Sorb to "being a bilingual Sorb," who accepts the risks, albeit not quietly, associated with mixing and not mixing linguistic resources.

As a national minority, Sorbs also feel this ambiguity in their split national loyalties - to the Sorbian nation, albeit without a state, and to the powerful German nation-state. Experiences of ambiguity also relate to the ideological and historical transformations. Based on the images of the German nation-state as a Nazi totalitarian regime (1933-1945), a Communist-ruled government dur- 
ing socialism (1945-1989), and a Member-State of the supranational European Union (post 1989), Sorbs frame past and present troubles as an unchanging dilemma. These images also correspond with historically specific language ideologies and policies: one nation-one language-one culture, native-speaker, and multilingual.

Although language policy under socialist rule enacted a more inclusive stance, the emphasis on socialist leanings for East German citizens simultaneously denied national and linguistic minorities their rights to self-determination. More specifically, Stalin's nationalities policies recreated a hierarchy in which Russian, but not German, was the official language. Now, in the European Union, exclusion of national/linguistic minorities reappears through policies of "benign neglect" (Nettle and Romaine 2000) and greater support for MemberState languages and not the lesser-used languages. Skutnabb-Kangas (1996) links monolingual reductionism, a reinvention of one language-one nation ideology, to EU language policy. Although not always explicitly stated in EU documents and language policy, current concerns reflect economic forces as a rationale for linguistic hegemonies that favor "world" languages. Furthermore, current policies support the "flowering of cultures" (Article 151 now Article 167, see also Creech 2005; Nic Shuibhne 2002; Xabier 2008). This thinly-veiled enactment of Herderian romanticism objectifies endangered/minority languages as national treasures. Heretofore, EU policy lacked an actual plan for protecting an endangered language community (Creech 2005). What remains constant from the mid-nineteenth century till the current moment is a one language-one nation-one culture ideology that reifies monolingualism.

As I focus on the historical moments that have led to contemporary affective discourses, I consider a grand narrative of Sorbian history from failed attempts to become an autonomous nation to the threat of extermination during the Third Reich. In comparing socialist and post-socialist texts, five critical moments emerge (Kasper 1987; Kunze 1995; Pech and Scholze 2003; Scholze 1999, 2003; Völkel 1969). These moments also symbolize broken promises. From the nationalizing meta-narratives of socialist/post-socialist texts, broken promises are often related to national desires, economic issues, and language policy aimed to protect the community. Behind the overt optimism of perseverance, Sorbian bilinguals are not blind or emotionally unaffected to the historical "cruelty" that they have survived while wrestling with personal commitments to use Sorb on a regular basis. As a final point, these temporal singularities not only engender a sense of cruel optimism, but also historically index transformations in linguistic well-being and political subjectivities.

To briefly summarize, Sorbian history centers around five instances of promising, when the community might have better survived national and linguistic uncertainty. First, Sorbian status of the Sorbs changed when the Slavic tribes became subordinated to the German tribes in the $10^{\text {th }}$ century. Between the $10^{\text {th }}$ and $19^{\text {th }}$ centuries, Sorbs were under the control of a Bohemian king, a Polish prince, and German royalty. These shifts in territorial control foreshadow contemporary discourses of non-national status and political ambiguities. Second, 
two separate communities (Upper Sorb and Lower Sorb) developed in the $19^{\text {th }}$ century. This process also coincided with the standardization of two literary languages associated with the Catholic and Protestant churches. Third, the Nazi regime posed a threat to Sorbs as an ethnic group and linguistic community in an aggressively racist stance that included banning the language, imprisoning key leaders, and closing the Sorbian schools. Fourth, Sorbs received meaningful state support during the socialist period although other socialist policy did not safeguard the survival of this Slavic national minority. Sorbs often referred to the destruction of Sorbian villages from brown lignite mining as one particularly destructive action of the socialist government. Fifth, in the newly imagined integration of the EU, despite the rhetoric of multilingualism, Sorbs experience a new threat as speakers of a lesser-used language, a people without a state but whose institutions face severe financial cutbacks, and a transnational minority with real fears about survival. ${ }^{3}$

With my own growing awareness of emotional dynamics, I began to recognize how Sorbs experience alienation through deeply felt, contested discourses about their worth as a polity and as individuals. During my visits to Sorbianspeaking households, I heard families talking about economic issues. Their economic anxieties bordered on a compulsive concern with funding reflecting a 2007 cut from 16 to 12 million Euros for language maintenance and cultural projects. This decrease and the ensuing redistribution of local monies brought economic concerns to the dinner table. Expressions of anger come from fears and realizations that losses in funding may threaten survival. Along with these economic anxieties, Sorbs are astutely aware of declining population due to falling birth rates, village loss, school closings, reduced production of Sorbian events, and emigration. These factors further contribute to a dismal prognosis. Furthermore, life choices; for example, going to a play, choosing a school, or reading the newspaper often inform the metalinguistics of TROUBLING TALK, because these decisions concern Sorbian/German options.

Specific concerns range from not having a Sorbian school to having a voice that will appeal to governmental entities (Saxon, German, European, or the imagined global community). These issues often reinforce that the global "others" are deaf to Sorbian concerns. At its most basic level, Sorbs fear that if their resources - their language, their voice, and their assets are not used, funded, or available, then they as a people and those resources that define them as Sorbs will be lost. As Sorbs embrace beliefs that their language is a "treasure" or approximate their worth according to population size or material objects (Hill 2002), they connect endangerment to economics through discourses of commodification of a fetishized language. This language ideology can overshadow attention to local perspectives. Thus, I take Hill's questions of "who is listening?" and "what do they hear?" a step further to ask "what are Sorbs saying?" and "how do the Sorbs feel about what they hear?"

${ }^{3}$ The high Saxon employment played in a significant role in the decision making of Sorbian youth to seek employment outside of Lusatia. 
At the heart of local discussions about endangerment is an awareness of loss and death, an everyday nearness to it. Like Reis found in Russian laments, talking about troubles "[...] reinforced social cleavages, deepened political apathy, and intensified a sense of despair and futility" (Reis 1997: 168) while providing a salve to these personal and collective wounds. What Tom, a theater worker, hears in "crying wolf," is a lived statement, a palimpsest of sentiments: fear of language death, exasperation at not being heard, anger at having to give the alarm for a long period and perhaps even surprise and hope that the Sorbian language and culture will survive the current dangers they face. Furthermore, the evocative evaluation hints at everyday language politics woven into gossip and finds fault with the acts of not being silent about language death. Thus, survival often becomes a metalinguistic activity of making sense of the past and the present. At the same time, sense-making can restrict everyday language use and aggravate already tense intra-Sorbian politics while providing for a healthy airing of grievances.

All the related talk about past injustices or the present decline can be unwanted. In talking about her co-workers and peers who worked in the Sorbian institutions, Charlotte positions herself against others using "they," when she says, "They think too much about the past." She differentiates herself from her colleagues who fixate on the past. Her accusation of historical obsession suggests an alternative - one in which Sorbs must focus on the present to address contemporary problems. Yet, she later contradicts herself saying that she felt happier during socialism (a time when the institutions were well supported). Her nostalgic identification with socialism speaks to another historical conundrum, "Are things better now for the Sorbs than they were under socialism?" The answer with respect to Sorbian lives is not an unconditional "Yes" or "No."

Asking this question is not meant to give a unilateral answer in all contexts, but rather an iteration of very real Sorbian concerns. When Pech asks:

In der Mitte der fünfziger Jahre wurden annähernd 100000 Sorben ermittelt, am Ende der DDR war die Zahl auf rund 60000 gesunken. Gerade diese Entwicklung scheint angesichts der weit reichende staatlichen Förderung unverständlich zu sein. Daraus ergibt sich die zentrale Fragestellung: Wie positv war die DDR-Minderheiten-politik wirklich? (Pech 2003: 102).

In the middle of the 1950's there would have been approximately 100,000 Sorbs; at the end of the G.D.R. the number had sunk to around 60,000. This development is incomprehensible in the face of costly state support. From this comes the central question. How positive was the G.D.R. minority politics really?

This loss in population is the most recent broken promise. Other unfulfilled promises include three attempts to become a separate nation-state: during the mid-nineteenth century participating in democratic revolutions that were part of larger European political shift to nationalized system of states, through a petition to President Woodrow Wilson at the Treaty of Versailles (1917), and in an appeal to Stalin during the Moscow Foreign Ministers' Conference (1947). This post-socialist commentary also hints at a state of unrest - a 
Sorbian community in a perpetual state of alarm repeatedly confronting their national demise.

Asking "how many?" veils the deeper issues of "who benefits?" from such questions and possible distortions (Duchêne and Heller 2007). Many of the questions that I asked Sorbs about endangerment would not be answered, but I realized that these questions sparked a host of emotional responses: pride, rote recitation of statistics, indirect anguish over the number of speakers and opportunities to express oneself in Sorb, political critique and, finally, adept INDISTINCTION. When I developed interviews that directly addressed other research questions (personal network size, education, language use), the formal questions made informants uncomfortable. What was often not said was that the current population of 8,000 speakers terrifies them. Their side-stepping of the question also reflects the ambivalence of a changing moral order (Friedman 2007). Although I did not want to "measure" Sorbian vitality in numbers, discussions of population size inherently encompass a fear of language death (Walsh 2005) evidenced in the post-socialist loss of 60,000 Sorbs. This discourse of culpability was and continues to be a locus of struggle on which Sorbs have a perspective, if not one they wish to articulate directly.

Linking personal choices with the political takes shape in what Yurchak defines a politics of INDISTINCTION as a broader "...understanding of what politics is, what forms it takes, what effects it may produce" (Yurchak 2008: 201). Yurchak reasons that the performance artists of the late Soviet years found inspiration in images of death and absurdity of life. The experiences of these artists are similar to daily encounters that Sorbs have with ideas of cultural and linguistic death as well as forms of German control and intra-community surveillance. As an embodied resistance, the artists' performances involved speaking incoherently with grunts and long pauses as well as avoiding analysis of their actions. This manipulation of language and avoidance resonates with many of my interview issues.

At the play "Zloty Palc" ('The Golden Finger'), Sorbs were reluctant to answer my questions. One particular response to the play stands out not only because I heard it at the play's premiere, but also in conversations about other theater performances. In the first act, a group of people accept the task of protecting a magical seed - a unique treasure of great beauty - from an evil witch. During the intermission, Hanka, a young village Sorb, introduced me to other Sorbs and I started talking about the story-line of the play. My interlocutors switched topics talking about the other people in the lobby. Recognizing that attendance seemed to be of more interest to them, I asked theater-goers about the social dynamics. Repeatedly they said, "to je katastrofa" ('it is a catastrophe'), a back-channel often used in talking about local politics. As I pressed further, they explained that there were not enough Sorbs coming to the play. However, village Sorbs had told me that they were not coming to the Bautzen theater. Inherently, describing the local politics as a catastrophe indexes urban-village discourses of difference and passionate resistance through talking about not going to a play or the everyday linguistic catastrophes. Yet, the worsening of 
well-being fuels not only a need to withdraw but also the passionate defiance to better one's life even if certain choices also compound linguistic wounds and shared worries.

Rethinking gossip warrants further explanation of urban-village stereotypes. Sorbs often criticize one another as hypocritical linking language use to particular spaces. Following are a series of critical comments from rural Sorbs about their urban counterparts that might be heard in the village, at the dinner table or in an interview addressing feelings about their troubles.

Sie sprechen Sorbisch nur da (They [Sorbs who work in Bautzen] speak Sorb only there [referring to an institutional workspace]).

Sie sprechen kein Sorbisch zu Hause (They do not speak Sorb at home).

Sie arbeiten nicht (They do not work).

Sie sind immer bei Kaffee (They are always on a coffee break).

These comments index the choices of urban Sorbs who may not speak Sorb at home, or withdraw from interactions with village Sorbs. Given these negative stereotypes villagers may refuse to visit sites in town like the theater, institutional spaces, or the tourist center. Villagers instead tend to pride themselves on speaking Sorb at home rather than "earning" their income from language maintenance efforts.

Another key category of TROUBLING TALK involves assessments of language use. In the following comments, I heard critiques of language used in plays or texts and in public spaces. These utterances below reveal personal tastes about language use or as Sorbs described it - sounding funny - that contribute to desires for INDISTINCTION, because all types of language use are subject to critique.

das klingt komisch (that sounds funny)

das ist Scheiß/e]sprache (that is shitty language)

das ist Quatsch (that is nonsense)

das ist entwickelt (that is invented)

Saying something sounds funny is a complicated part of TROUBLING TALK similar to various associated meanings with "crying wolf." For example, if a Sorbian utterance is too pure or too impure, then it sounds funny. It is hard to find middle ground in one's speech contributing to the need to make finical evaluations. These comments also provide a rationale for choosing not to speak Sorb and exemplify the risks in mixing or not mixing resources. However, I must stress that mixing is not primarily about Sorbian-German differences. Although these critiques explain why a Sorb may move away from urban/village spaces while positioning other Sorbs in those undesirable contexts, they are not apathetic stances. Rather, critiques embody linguistic passion.

Like Dorian (2001), I am grateful that many Sorbs griped about the "troubles," narrated their personal dilemmas while letting me see their "pain," and refused to let me record. Complaining about personal stresses and negative comments about language use introduced me to Sorbian awareness of historical 
influences on their present lives, their active choices to speak or not to speak Sorb, and the complexities of InDISTINCTION. Inspired by Bakhtin's (1986) notion of heteroglossia, I acknowledge that linguistic consciousness is multiple, dialogic, and emotional. This consciousness resonates with a shared history filled with the troubles that Sorbs talk about at length.

While socialist narratives resonate with a David and Goliath theme, Köstlin (2003) suggests that a new pessimistic tone characterizes Sorbian discourses of cultural/linguistic survival. This pessimism reveals that "unhappiness" is part of a current reality of Sorbs being "sterbender Europäer" ('dying Europeans'). Ironically, this estimation compares with the theater's workers accusation of "crying wolf." Political discussions often lay blame at specific broken promises to protect or support Sorbian interests. The post-socialist state of affairs exposes sense-making strategies of broken promises that have become personalized. Personal gains and losses are often associated with the materiality of language endangerment: the loss of Sorbian villages and schools with loved ones; political attempts to attain sovereignty and protection with national apathy; and the broken promises of the American government, Hitler, the Red Army, Stalin and the European Union with a sense of political alienation. In general, economic discourses are linked to urban-village stereotypes while issues related to language death are connected to personal troubles.

The ethnographic examples of TROUBLING TALK and historical dimensions of Sorbian troubles reinforce a politics of INDISTINCTION. I propose that an anthropological approach to local talk about language endangerment merits theoretical attention for several reasons. First, I expose how broken promises have real impact on emotional and linguistic well-being. Second, by taking into account how being unsure about one's political, linguistic, and national survival may contribute to fighting for one's language in alternative ways, new perspectives on endangerment will emerge. In other words, I summon the evidence to show how endangerment becomes introverted as a private battle waged every day at the dinner table, in the basement, in their garden, or in an interview. Third, I refocus attention on intra-cultural politics while being aware of how bilinguals monitor themselves and other bilinguals. From this, I hope to offer anthropological perspective on power and language use by providing another view on the everyday politics of linguistic survival. From a broader perspective, INDISTINCTION is a stance that many citizens in a globalized world embody while coping with disappointments and trying to create a better life.

\section{REFERENCES}

Lila ABU-LUGHOD, 1986: Veiled Sentiments: Honor and Poetry in Bedouin Society. Berkeley: University of California Press.

Sara AHMED, 2010: The Promise of Happiness. Durham: Duke University Press. 
Mikhail BAKHTIN, 1981: Discourse in the Novel. The Dialogic Imagination: Four Essays by M.M. Bakhtin. Michael Holquist, ed. Caryl Emerson and Michael Holquist, trans. Austin: University of Texas Press. 259-422.

Gregory BATESON, 1935: Culture, Contact, and Schismogenesis. Man 35, 178-183.

Lauren BERLANT, 2011: Cruel Optimism. Durham: Duke University Press.

Niko BESNIER, 2009: Gossip and the Everyday Production of Politics. Honolulu: University of Hawai'i Press.

Jan BLOMMAERT, 2004: Rights in Places: Comments on Linguistic Rights and Wrongs. Language Rights and Language Survival: Sociolinguistic and Sociocultural Perspectives. Jane Freeland and Donna Patrick, eds. Manchester UK: St. Jerome Publishing. $55-66$.

Pierre BOURDIEU, 1984: Distinction: A Social Critique of the Judgement of Taste. Richard Nice, trans. Cambridge: Harvard University Press. Cambridge University Press.

Pierre BOURDIEU, 1991: Language and Symbolic Power. John Thompson, ed. Gino Raymond and Matthew Adamson, trans. Cambridge, Mass.: Harvard University Press.

Peter BROCK, 1969: Smoler's Idea of Nationality. Slavic Review 1, 25-47.

Jillian CAVANAUGH, 2009: Living Memory: The Social Aesthetics of Language in a Northern Italian Town. Oxford: Wiley-Blackwell.

Richard CREECH, 2005: Law and Language in the European Union: The Paradox of "United in Diversity." Groningen: Europa Law.

Nancy DORIAN, 2001: Surprises in Sutherland: Linguistic Varaibility amidst Social Uniformity. Linguistic Fieldwork. Paul Newman and Martha Ratliff, eds. Cambridge: Cambridge University Press. 133-151.

Alexandre DUCHÊNE, Monica HELLER, 2007: Discourses of Endangerment: Sociolinguistics, Globalization and Social Order. Discourses of Endangerment: Ideology and Interest in the Defense of Languages. Alexandre Duchêne and Monica Heller, eds. London: Continuum. 1-13.

Jack FRIEDMAN, 2007: Shame and the Experience of Ambivalence on the Margins of the Global: Pathologizing the Past and Present in Romania's Industrial Wasteland. Ethos 35 (2), 235-264.

Jane HILL, Kenneth HILL, 1986: Speaking Mexicano: Dynamics of Syncretic Language in Central Mexico. Tuscon, AZ: The University of Arizona Press.

Jane HILL, 2002: "Expert Rhetorics" in Advocacy for Endangered Languages: Who Is Listening, and What Do They Hear? Journal of Linguistic Anthropology 12/2, 119-133.

Katherine HOFFMAN, 2008: We Share Walls: Language, Land, and Gender in Berber Morocco. Oxford: Wiley-Blackwell.

Martin KASPER (ed.), 1987: Language and Culture of the Sorbs throughout their History. Berlin: Akademie Verlag.

Peter KUNZE, 1995: Kurze Geschichte der Sorben. Bautzen: Domowina-Verlag. 
Konrad KÖSTLIN, 2003: Lust auf Sorbischsein. Im Wettstreit der Werte: Sorbische Sprache, Kultur und Identität auf dem Weg ins 21. Jahrhundert. Dietrich Scholze, ed. Bautzen: Domowina-Verlag. 427-445.

Daniel NETTLE, Suzanne ROMAINE, 2000: Vanishing Voices: The Extinction of the World's Languages. Oxford: Oxford University Press.

Edmund PECH, Dietrich SCHOLZE, eds. 2003: Zwischen Zwang und Beistand: Deutsche Politik gegenüber den Sorben vom Weiner Kongress bis zur Gegenwart. Bautzen: Ludowe Nakładnistwo Domowina.

Nancy REIS, 1997: Russian Talk: Culture \& Conversation during Perestroika. Ithaca: Cornell University Press.

Leoš ŠATAVA, 2005: Sprachenverhalten und ethnische Identität. Budyšin (Bautzen), Germany: Domowina-Verlag.

Dietrich SCHOLZE, 1999: Die Sorben in Deutschland. Görlitz, Germany: Maxroi Graphics.

Dietrich SCHOLZE, 2003: Einleitung: 50 Jahre sorabistische Forschung in Bautzen (Zawod: 50 lět sorabistiske slědźenje w Budyšinje). Wettstreit der Werte: Sorbische Sprache, Kultur und Identität auf dem Weg ins 21. Jahrhundert, Dietrich Scholze, ed. Bautzen: Domowina-Verlag. 15-20.

Tove SKUTNABB-KANGAS, 1996: Educational Language Choice: Multilingual Diversity or Monolingual Reductionism? Contrastive Sociolinguistics. Marlis Helliger and Ammon Ullrich, eds. Berlin: Walter de Gruyter. 175-204.

Niamh NIC SHUIBHNE, 2002: EC Law and Minority Language Policy: Culture, Citizenship and Fundamental Rights. The Hague: Kluwer Law International.

Elka Tschernokokoshewa, Marija Jurić-Pahor, 2005: Auf der Suche nach hybriden Lebensgeschichten; Theorie, Feldforschung, Praxis. Münich: Waxmann.

Pawoł VÖLKEL (ed.), 1969: Die Sorben: Wissenwertes aus Vergangenheit und Gegenwart der sorbischen nationalen Minderheit. Bautzen: Nowa Doba, Druckerei der Domowina.

Michael WALSH, 2005: Will Indigenous Languages Survive? Annual Review of Anthropology 34, 293-315.

James WILCE, 1998: Eloquence in Trouble: The Poetics and Politics of Complaint in Rural Bangladesh. Oxford: Oxford University Press.

James WILCE, 2009: Crying Shame: Metaculture, Modernity, and the Exaggerated Death of Lament. Oxford: Wiley-Blackwell.

Arzoz XABIER (ed.), 2008: Respecting Linguistic Diversity in the European Union. Amsterdam: John Benjamins.

Alexei YURCHAK, 2008: Necro-Utopia: The Politics of Indistinction and the Aesthetics of the Non-Soviet. Current Anthropology 49/2, 199-224. 


\section{PROBLEMATIČNI DISKURZ: POLITIKA IN ZGODOVINA NEJASNOSTI V GORNJELUŽIŠKI SKUPNOSTI}

Prispevek se posveča jezikovni politiki v gornjelužiški skupnosti. Avtorica uvaja pojem nejasnosti (indistinction), da bi dosegla bolj niansiran način razmišljanja o znotrajskupnostnih socialnih odnosih in jezikovni politiki. Govor o zgodovinskih in sodobnih težavah v kontekstu tega ogroženega slovanskega jezika razkriva dinamiko preživetja in izgub, ki pogosto sovpadajo s strateškimi in politiziranimi izbirami jezikovne rabe. $\mathrm{S}$ pozornostjo, usmerjeno na osebno in kolektivno nezadovoljstvo $\mathrm{z}$ rabo jezika in na zgodovinske okoliščine, avtorica razreši stičišča med jezikovno prakso, čustvi in jezikovno politiko.

$\mathrm{Na}$ osnovi uporabljenega koncepta nejasnosti avtorica zagovarja tezo, da Lužiški Srbi pogosto čutijo družbeni in politični pritisk, da ne želijo govoriti lužiščine oz. se ne odločajo za ohranjanje jezika. Te odločitve so obenem znak upora, ki se pojavi v problematičnem diskurzu. Vendar pa jezikoslovci pogosto opredeljujejo zavračanje govora $v$ nekem jeziku kot dejavnik, ki prispeva k jezikovni zamenjavi. Ob vnovičnem premisleku avtorica ugotavlja, da nejasnosti zadevajo probleme, vezane na jezikovno preživetje; številne težave Lužiških Srbov so namreč povezane z družbenimi odnosi in ne le z nemškim zatiranjem. Jezikovno politiko lužiške srbščine dodatno otežujejo pomembne zgodovinske spremembe. Od pojava nacionalističnih čustev sredi devetnajstega stoletja do postsocialističnih večnarodnih pripadnosti v Evropski uniji so namreč Lužiški Srbi narodna manjšina, avtohtoni prebivalci, ljudje (»Volk«), ki so si prizadevali za opredelitev dvojezične skupnosti v globaliziranem svetu.

Avtorica prispevka dodaja tudi etnografske podatke in zgodovinske pripovedi, ki jih Lužiški Srbi kot govorci ogroženega jezika poskušajo osmisliti. V poskusu razumevanja lastne zgodovine imajo namreč mešane občutke o svoji jezikovni identiteti. Pogosto se pritožujejo nad lastnimi življenji in jezikovnim okoljem, hkrati pa kot dvojezični občutijo nekakšen življenjski optimizem, ki sproži sprejemanje izgube in občutek krutega optimizma. Z drugimi besedami, lužiškasrbskost ne temelji zgolj na govorjenju lužiščine, temveč tudi na dejstvu, da govorci niso zmožni oz. ne želijo zmeraj biti lužiško govoreči. Problematični diskurz predstavlja čustveno naravnanost, ki je na presečišču zavezanosti lužiški jezikovni rabi in želji govorcev, da ne govorijo lužiščine. Ta napetost med strastnim kljubovanjem $\mathrm{z}$ nerabo jezika $\mathrm{v}$ določenih okoliščinah in opravljanje lokalnih ter zgodovinskih težav razkriva, kako govorci bijejo boj proti jezikovnemu umiranju. Politika nejasnosti vsekakor presega specifiko slovanskega konteksta z osredotočenostjo na politiko znotraj skupnosti in odporom kot dejanjem nejasnosti. 